\title{
Uma literatura de fronteira: Jorge Luis Borges, ficções e debates
}

Pablo Rocca | UDELAR

Resumo: A literatura de Borges, celebrada atépoucos anos como a mais refinada expressäo dos recursos universais em língua espanhola, fora do contexto e dos problemas mais marcantes da América Latina, reservou, no entanto, uma tensão muito forte com outros textos que falam e debatem os problemas politicos destas terras. Este artigo indaga essas relaçôes e, sobretudo, a posição fronteiriça da obra borgiana nos planos simbólico e político em confronto com os Estados do Rio da Prata e o Brasil.

Palavras-chave: Jorge Luis Borges, fronteira, Argentina, Brasil, Uruguai.

\section{Limites do problema}

Beatriz Sarlo acredita que a ficção em Borges contrasta "duas culturas, duas línguas, duas histórias. Nesse sentido, a literatura de Borges é de fronteira: vive da diferença". ${ }^{1}$ Esta diferença implica, em primeiro lugar, algo que sempre foi muito pesquisado pela crítica borgiana, algo particularmente incomodo para os

1. SARLO. Borges, un escritor en las orillas, p. 108. 
conflitantes nacionalistas argentinos, desde Raúl Scalabrini Ortiz até Jorge Abelardo Ramos: um escritor de língua castelhana que vive a experiência de outras línguas e o faz, em grande proporção, em outros idiomas; por esse motivo habita um espaço discursivo de fronteira.

Como se tratará de mostrar neste artigo, não apenas nesta trajetória estamos ante uma literatura de fronteira, mas também em um sentido topológico, simbólico e, em último termo, político, estratégia criativa assumida com plena consciência que, de resto, remete à primeira proposição.

Por um lado, então, a literatura de Borges ensaia a miscigenação e a síntese das culturas e os textos de diferentes línguas. Claro que o recurso e o processo não são desconhecidos. E mais ainda, seria possível dizer que numa expressiva proporção tal modus operandi é uma marca típica da cultura latino-americana e em especial do Rio da Prata, desde as próprias origens de sua vida autônoma. Em todo caso, nas letras hispano-americanas até Borges nunca havia sido vivida de forma tão radical como a proposta e ordenada em sua obra. Em boa medida derivada desta que podemos chamar fronteira da lingua e das literaturas, se baseia a atitude de Borges ante o que é nacional em todas suas dimensões e, por conseguinte, ante a literatura argentina. É possível acrescentar, como tentaremos provar aqui, que os textos de Borges penetram e extrapolam a literatura argentina, já que lhe preocupam o problema da fronteira, os sujeitos e os mitos envolvidos na comarca dos Pampas, tanto do lado castelhano como - numa proporção considerada negativa no sul do Brasil. É possível se identificar, sobre esse ponto, três variáveis fundamentais deste contato entre a vivência daquilo que é imediato e próprio, às vezes até numa aproximação empírica, com as textualidades que o representam ou o debatem:

1) A literatura gauchesca como espaço de debate, em particular seu texto-chave (o Martín Fierro, de José Hernández), e suas variantes.

2) A literatura "culta" ou, melhor, a produzida pelo setor letrado urbano que no curso da primeira metade do século XIX edificou a cidade letrada em franca oposição ao meio rural e aos seus personagens arquetípicos (o gaúcho, o caudilho). Nesta série se destaca o Facundo, de Domingo F. Sarmiento.

3) Os desafios a esta dupla vertente central que oferece um texto impossível de classificar: The purple land, de W. H. Hudson, e a ulterior introdução do problema da fronteira, que se traslada a sua própria obra ficcional. 


\section{Duas visões do mundo}

Para Borges, o gaúcho é a figura que adquire no pampa americano a universal silueta do vaqueiro:

Ser gaúcho foi um destino. Aprendeu a arte do deserto e seus rigores (...). Não foi, como seu remoto irmão do Far West, um aventureiro, um explorador de terras virgens distantes ou de filões de ouro, mas as guerras o levaram muito longe e deu valorosamente sua vida, em remotas regiões do continente por devaneios que nem ele mesmo chegou a compreender - a liberdade, a pátria - ou por uma insígnia ou um chefe. ${ }^{2}$

Como desde muito antes se vinha pensando, Borges convencionou que, com El gaucho Martín Fierro, publicado em 1872 e, sete anos depois, com a segunda parte da obra (La vuelta de Martín Fierro), José Hernández coroou o processo desta linha literária no Rio da Prata. Ou, dito de outro modo, com o poema de Hernández todos os recursos e aprovisionamentos do gênero chegam a tal grau de elaboração que o colocam em um lugar de muito debate no campo da literatura latino-americana. Se durante décadas foi possível ler o poema de Hernández como o ponto máximo de um gênero, por outro lado fica claro que, na sua época, Martín Fierro foi uma resposta política à obra Facundo. Civilización y barbarie en la República Argentina (1845), a obra decisiva do seu oponente que havia deslumbrado à intelligentsia latino-americana. É sabido que a Sarmiento correspondeu consolidar nesse livro a fixação de um rígido esquema que se assenta, num jogo de pares antinômicos: civilização contra barbárie, letrado contra gaúcho, cidade-porto-cultura versus campo-deserto-ignorância. Na obra Facundoé a primeira vez em que se faz um estudo do gaúcho com pretensões sociológicas, descrevendo-o como preguiçoso, brutal, supersticioso, hábil no uso da faca, vaqueiro experiente e cantor. O caudilho, ao qual Sarmiento personifica em Facundo Quiroga e, sobretudo, em Juan Manuel de Rosas, não é mais que um produto da fatalidade do meio: "não vejo simplesmente um caudilho, mas uma manifestação da vida argentina tal como foi produzida pela colonização e pelas peculiaridades da terra". A essência deste "mal" está na natureza bárbara do mestiço, traço selvagem que se agrava mais ainda no índio e no negro.

2. BORGES. Prólogos con un prólogo de prólogos, p. 62. 
Muitas vezes se foi mais longe chegando até a propor que Martín Fierro é uma espécie de antiFacundo. O conflito é evidente: Sarmiento demoniza o "deserto" como uma forma de confinar em Rosas a síntese do gaúcho e, em consequência, do que é primitivo e abominável. Hernández, em troca, resgata o pampa como território onde é possível dominar o trabalho e o progresso material, e ao mesmo tempo percebe o gaúcho como o autêntico "barro nacional". Os narradores escolhidos tanto em uma como na outra obra pautam essa perspectiva divergente. No texto de Sarmiento uma voz que pertence ao autor-narrador conta a história de Facundo Quiroga; ao longo do poema de Hernández, como em todos os outros do mesmo gênero, é o próprio gaúcho quem conta sua biografia em verso. Entretanto, apesar destas claras diferenças de técnica e de enfoque não há na ideologia de Hernández utilização de todos os termos propostos por Sarmiento. Se este assume desde o começo toda a violência excludente do liberalismo portuário, "em Hernández - conforme Noé Jitrik - o processo de síntese é mais lento: através da defesa ou elegia do gaúcho termina - não começa - por justificar o mundo de suas ideias liberais cuja eficácia se faz evidente ao final da sua vida". 3

De fato, como sugere Jitrik e mais tarde é estudado por Tulio Halperin Donghi, à margem das ferozes disputas políticas cotidianas, na segunda parte do poema do seu antagonista, Sarmiento pode ler a confirmação de muitas de suas ideias sobre o progresso argentino, isto é, da consolidação do capitalismo moderno nesse país. Os sete anos que separam a ida da volta de Martín Fierro mudam o perfil político da Argentina e o do próprio autor do poema gauchesco logo erigido no clássico, tolerado pela elite culta das cidades rio-pratenses que vinha ganhando a batalha da domesticação do gaúcho em cidadão. Há, contudo, outras fortes diferenças que não mudam. Sarmiento postula que o exército é a única saída imediata para civilizar "a gente do país"; por outro lado Hernández acredita que a instituição militar obriga, incomoda e maltrata o gaúcho, não lhe deixando outra escapatória que sair dela como delinquente, como "desertor". Em Martín Fierro a farda transforma o homem em matreiro, assassino, ladrão, prófugo e, finalmente, em um refugiado entre os índios. Ao invés de integrá-lo à "civilização", o exército o anula como força produtiva, o transforma em um perigoso elemento perturbador da lei e da ordem.

Após algumas décadas nas quais o poema usufruiu tanto do prestígio popular como de um moderado esquecimento por parte dos intelectuais portenhos,

3. JITRIK. José Hernández, p. 2. 
no começo do século XX Martín Fierro será redimido por uma interpretação nacionalista e conservadora. Para os porta-vozes desta reivindicação, Leopoldo Lugones e Ricardo Rojas - assim como era antes para o uruguaio Francisco Bauzá -, o gaúcho e o "deserto" deixam de ser fonte de barbárie e passam a resumir a identidade nacional. Os antes reclamados imigrantes europeus chegam como em uma enxurrada nas primeiras décadas do novo século e, para cúmulo, entre os laboriosos estrangeiros chegam os anarquistas, uma presença que aterroriza o poder e onde a própria essência da "argentinidade" se vê ameaçada. O gaúcho passa a ser mistificado, já que ficara para trás o tempo em que servia de partidários do caudilho e se transformara em peões de fazenda, assalariado rural, soldado de linha ou em um mero desocupado que engrossa os cinturões de miséria nos centros urbanos, mas que ainda não encontrou um canal de expressão para sua previsível rebeldia.

Para Borges, o gaúcho sobrevive apenas como personagem da literatura, mesmo acreditando que a literatura que pretende cumprir uma função documental ou mistificadora ou meramente política sempre está condenada ao fracasso, nunca deixará de recorrer a este manancial. Somadas suas páginas ensaísticas sobre o gênero, abundam quaisquer outras de suas preferências. Mesmo que no gaúcho real ou literário, e os dois costumam se confundir dentro e fora da obra de Borges - muitas vezes ao seu pesar -, haja um traço, o redentor individualismo, que aparece como solução interpretativa para o indivíduo e seu meio. "Nuestro pobre individualismo", foi o título dado por Borges a um dos seus artigos incluído em Otras inquisiciones (1952), no qual declara seu horror ante o Estado, o caudilho e qualquer forma de poder supraindividual:

O argentino, ao contrário dos norteamericanos e de quase todos os europeus, não se identifica com o Estado. Isso pode ser atribuído à circunstância de que, nesse país, os governos habitualmente são péssimos ou ao fato geral de que o Estado é uma abstração inconcebível; o certo é que o argentino é um indivíduo não um cidadão. ${ }^{4}$

Essa indireta negação do herói associado ao condutor do Estado se origina de Sarmiento, mas já se encontrava explícita no solitário romance de Jorge Guillermo Borges: El caudillo (1921). Nas primeiras páginas do capítulo inicial, o pai do então escritor ultraísta, denuncia "o gaúcho obstinado em seu gauchismo

4. BORGES. Prosa completa, II, p. 161. 
anacrônico, que queria continuar sendo gaúcho, como afirmou Sarmiento". 5 caudilho imaginado no romance epônimo, aparentemente civilizado ou com uma abertura rumo ao progresso infinitamente maior ao de Juan Facundo Quiroga que pintou Sarmiento, acaba atuando com violência contra um portenho, a quem sua filha ama, na sua província de Entre Rios durante a insurreição de Raúl López Jordán. Deste caudilho tinha sido secretário e apologista nada mais, e nada menos, que José Hernández.

Pela soma destes fatores, destes pretextos que se acumulam em seu arquivo, antes que a literatura que exalta o caudilho ou ao chefe, Borges resgata na literatura argentina (ou do que chamaremos a pampa ocidental) uma "desesperada noite na qual um sargento da polícia rural gritou que não iria permitir o delito de que se assassinasse a um valente e começou a lutar contra seus soldados, junto ao desertor Martín Fierro". 6 Sobre essa noite trata seu breve conto "Biografia de Tadeo Isidoro Cruz". No momento do relato, Cruz se recusa a entrar na cidade, é um homem da pampa e, portanto, nunca poderia franquear a fronteira entre a cidade e o campo.

Em uma frase de Thomas Carlyle, "a história do mundo é a biografia dos grandes homens", Borges encontra uma antecipação do nazismo e, como corolário evidente, de todas as formas que acreditava subsidiárias. ${ }^{7}$ Por exemplo, o peronismo. Em lugar do grande homem, eleva o herói anônimo. Nada melhor que o espaço das margens e da fronteira para a manifestação deste personagem que redime a todos, sem uma noção clara da lei, ou em todo caso, anulando o peso da norma jurídica em privilégio da ética individual como último limite. Não o chefe nem sua homogênea hoste, mas o solitário - como Cruz, como Fierro - até o mais agreste de todos os indivíduos que sem pedir nada se sobressai e, às vezes, até se sacrifica por todos.

A gauchesca contribui com um ingrediente fundamental para a interpretação borgiana da história argentina: a ética individual que se levanta sobre o servilismo e "a mera disciplina usurpando o lugar da lucidez", que impõem as ditaduras e os caudilhos. "Combater essas tristes monotonias - registra em um texto antiperonista de circunstância - é um dos muitos deveres do escritor". E conclui, se reafirmando em seu próprio ser: "Terei de lembrar aos leitores de

5. BORGES. El caudillo, p. 30.

6. BORGES. Prosa completa, II, p. 162.

7. BORGES. Prólogos con un prólogo de prólogos, p. 35-36. 
Martín Fierro e de Don Segundo [Sombra] que o individualismo é uma velha virtude argentina?”8 Com a exclusão desta certeza invariável são, contudo, muito grandes as oscilações valorativas nas quais incorreu Borges em relação a este poema fundamental da literatura latinoamericana. Em um artigo de 1931, que aparece na revista Sur, apenas confere a Martín Fierro capacidade na execução de um procedimento retórico: o de "cantar recordando". Assim que conforme o Borges daquela época, Hernández apenas queria contar uma história sem outras pretensões. De acordo com tal hipótese, como opinou muito contrariado Juan Fló, "não houve o mais mínimo interesse [por parte de Borges] em nos comunicar absolutamente nada sobre as condições sociais e políticas que realizaram essas vidas". "Vinte anos mais tarde, em 1953, a perspectiva é mais moderada. Borges passa a reconhecer que o livro "tem muito de argumentação política", e depois exagera dizendo que "a princípio, não o julgaram esteticamente, mas apenas pela tese que defendia". ${ }^{0}$ Em outra de suas típicas hipérboles, também duas décadas depois, em pleno apogeu do peronismo radical, foi mais longe propondo que "é um livro muito bem escrito e muito mal lido. Hernández o escreveu para mostrar que o Ministério da Guerra (...) fazia do gaúcho um desertor e um traidor; Lugones elevou esse desventurado à condição de paladino e o propôs como símbolo da identidade nacional. Agora sofremos as consequências". ${ }^{11}$ Seja como for, há um deslinde atrativo que vai da conclusiva opinião original que reduz o texto a um argumento apenas bem contado até o reconhecimento repentino da crassa realidade e, por último, a analogia entre texto, leitura consagratória e suas consequências ideológicas no contexto social.

Há algo em comum em todas as leituras de Martín Fierro feitas por Borges, e é que este não foi o livro que escreveu Hernández (ou não foi somente esse livro), mas o que leu a crítica nacionalista, responsável pela exaltação da barbárie. Entretanto, a fúria antinacionalista de um Borges maduro colide em um determinado ponto com o Borges jovem, que participou ardentemente de uma revista literária de vanguarda que se chamava Martín Fierro (1924-1927). Se o

8. BORGES. Ficcionario. Una antología de sus textos, p. 224.

9. FLÓ. Vindicación o vindicta de Borges. p. 171.

10. BORGES (en colaboración con Margarita Guerrero). El Martín Fierro, p. 73 .

11. BORGES. Prólogos con un prólogo de prólogos, p. 99. 
primeiro descarta toda e qualquer forma de nacionalismo e recusa o mito do gaúcho como símbolo da identidade nacional, o outro - o jovem - recuperava a escrita da "cidade letrada" para concluir: "Ser argentino nos dias de luta da nossa origem certamente não foi um prazer: foi uma missão. Foi uma necessidade de criar a pátria, foi um fascinante risco, que comportava, por ser risco, um orgulho. Agora é a tranquila ocupação do argentino."12

Dois casos aos quais Borges se refere, sobre episódios da literatura e da vida literária crioula, falam do distanciamento severo que há frente a toda posição nacionalista do fenômeno gauchesco. Conta que em certa ocasião, em 1911, o famoso bandoleiro e caudilho da orilha portenha conhecido como Hormiga Negra se apresentou ante os irmãos Pablo e José Podestá para lhes avisar que, caso fosse apresentada em sua companhia teatral uma obra sobre sua vida, iriam se arrepender amargamente. ${ }^{13}$ Em outra ocasião, Borges consigna que, pela representação de determinados personagens em seu romance Don Segundo Sombra (1926), Ricardo Güiraldes foi ameaçado "pelos bandoleiros mais conhecidos de Areco: 'El Toro', seu filho 'El Torito' e Andrés Soto, incomodados pela sua gloria literária. O velho 'don Segundo' era homem de paz e morreu entre a fama e a justificada desventura". ${ }^{14}$ Estas referências servem para tratar de submeter sua hipótese de que "toda forma de arte, inclusive a naturalista, é convencional". 15 Além disso, servem também para reforçar sua fé em um dos valores mais admirados por sua antiguidade e prestígio literário: a coragem. "Sua pobreza teve um luxo: a coragem", disse sobre o gaúcho. ${ }^{16}$ Uma ideia muito reiterada em sua poesia e em sua prosa e, também, introduzida pelo seu mérito, um pouco mais degradada, foi o compadrito dos arrabaldes da cidade grande, isto é, um personagem desafiante e corajoso, um caudilho em pequena escala.

Em circunstâncias políticas e culturais muito diferentes das que protagonizaram Lugones e Rojas, nos começos dos anos 1970, o texto de Hernández serviu para outras perspectivas. Então, com a volta do peronismo ao poder, seu texto foi lido em tom populista e ao mesmo tempo revolucionário, como no filme Los hijos de fierro, de Fernando Solanas. Poucas vozes se levantaram contra estas

12. BORGES. El idioma de los argentinos, p. 146.

13. BORGES. Prólogos con un prólogo de prólogos, p. 31.

14. BORGES. Prólogos con un prólogo de prólogos, p. 63.

15. BORGES. Prólogos con un prólogo de prólogos, p. 29.

16. BORGES. Prólogos con un prólogo de prólogos, p. 63. 
novas apropriações nacionalistas com matizes socializantes. Uma delas foi a de Jorge Luis Borges, quem sarmientinamente entendeu que em 1974 uma exaltação do gaúcho e de seus governantes (principalmente sobre um governante: Juan Manuel de Rosas) não era mais que a consagração-reencarnação do caudilho (que agora se chamava Juan Domingo Perón) e de suas massas, originárias do interior, ou seja, esses longínquos herdeiros dos gaúchos, aqueles que agora são conhecidos como "cabecinhas negras" ou "descamisados", os que enalteciam o abominado novo líder. Naquele 1974, eufórico tanto para as massas como para as minorias que sonhavam com a revolução popular argentina, no prólogo de uma edição de Facundo, Borges refletia de modo perfeitamente assimétrico a sua perspectiva, já citada, sobre o poema de Hernández: "No que nos diz respeito, penso que nossa história seria outra, e seria melhor, se tivéssemos elegido, a partir deste século, a Facundo e não a Martín Fierro." ${ }^{17}$ E, também, de maneira perfeitamente simétrica, recuperava a vigência de uma leitura e sua disseminação na série de leituras que cristalizam uma ideologia.

Dois poemas escritos em duas épocas distintas, um em sua juventude, os outros após os cinquenta exemplificam estas obsessões. O primeiro, "El general Quiroga va en coche al muere", é uma condenação da barbárie e da prepotência caudilhesca, é quase a celebração da morte de Facundo Quiroga, o qual se dirige a Barranca Yaco, onde "una de puñaladas" o derruba e o conduz ao "Infierno que Dios le había marcado". A outra peça, "Poema conjetural”, é um símbolo, em tom patentemente pessoal, da exaltação do drama do intelectual nestas terras, a expiação do encontro com um "destino sudamericano", o da violência, o da morte em um lugar remoto, misturado ao sangue dos gaúchos. Sua preferência pelo "Poema conjetural", que foi incluído em todas as suas antologias pessoais e, de fato, a introdução recitada deste texto na conferência sobre a gauchesca que pronunciou em Montevidéu em 1945, em plena ascensão de Perón, ${ }^{18}$ fala desse desvelo por uma literatura que, de tanto contaminar a realidade, se torna política para uso dos que ele considera demagogos e manipuladores populistas. Ao mesmo tempo, como movimento inverso, esse mesmo poema volta ao infindável conflito do intelectual urbano quem, ainda contrariado, é obrigado a abandonar o recinto sagrado da biblioteca nos duros tempos de luta "dos outros", daqueles que vencem: "los bárbaros", "los gauchos". A justificativa, agora pessoal, com um forte matiz imposto

17. BORGES. Prólogos con un prólogo de prólogos, p. 139.

18. BORGES. Aspectos de la poesía gauchesca, p. 33-34. 
pela circunstância e sua dramática elevação, se fortalece através do artifício retórico de fazer "pensar" a Laprida pouco "antes de morir". Através da voz de Laprida, Borges teme pela vida da sua gente, sua visão dicotômica lhe produz o terror ante o triunfo cíclico da parte não nobre e brutal da nação em detrimento da minoria ilustrada que pode redimi-la. A literatura gauchesca, como qualquer outro gênero, atravessa épocas de calma - como nos idealizados anos vinte - e se transforma em ferramenta política, texto de denúncia, em épocas de inquietação e ruína. A história, em suma, apesar do solipsismo borgeano, recobra seu sentido.

\section{Pampa ocidental e Pampa oriental}

Algo desse projeto se cumpre em Don Segundo Sombra. Nesse romance, Güiraldes imagina a vida de uns poucos personagens na pampa argentina, afirmando assim o mítico espaço fundacional da nação crioula, à margem de conflitos sociais ou de classe e em contato permanente com o campo, entendido como distância, quase infinita, horizonte sobre si mesmo. Güiraldes havia escrito esse texto apelando aos recursos modernos, aos que a estética ultraísta elevou à categoria de absolutos: a metáfora, a elipse, o uso da comparação inusitada ou pouco usual dentro do modelo realista, a rejeição da pura descrição naturalista.

Num ensaio reunido em El tamaño de mi esperanza, publicado no mesmo ano de Don Segundo Sombra, Borges reclamava o romance sobre "o cabal símbolo pampeano, cuja figuração humana é o gaúcho" ${ }^{19}$ Terminado esse projeto do qual, como é obvio já se tinha notícia em1926, em uma nota datada de 11 de agosto de 1934, comentando a tradução inglesa do romance de Güiraldes, associa esse livro com firmeza ao Huckleberry Finn e, de passagem, ao romance Kim, de Rudyard Kipling: "Mark Twain, Kipling, Güiraldes: outra vez perseguirei as afinidades, os vínculos secretos e manifestos destes três altos nomes." ${ }^{20}$ Em um prólogo de 1968, dirá que no romance do seu compatrício "tudo é elegíaco. De algum modo sentimos que cada um dos fatos narrados ocorre pela primeira vez." ${ }^{, 21}$

19. BORGES. El tamaño de mi esperanza, p. 23.

20. BORGES. Borges en Revista Multicolor. Obras, reseñas y traducciones inéditas de Jorge Luis Borges. Diario Crítica: Revista Multicolor de los Sábados, 1933-1934, p. 204.

21. BORGES. Prólogos con un prólogo de prólogos, p. 65. 
Com certeza, algo muito parecido ao que Mário de Andrade havia dito em meados da década de 1920, opiniões que Borges mal pôde conhecer: "num assunto rapsódico de vida pampeana [Don Segundo Sombra encontrou] o equilíbrio entre a tendência criadora, o realismo observador, a dicção refinada e a fatalidade nacional". ${ }^{22}$ Em "O escritor argentino e a tradição" (1953), arguirá que Don Segundo Sombra, sem deixar de ser um livro nacional, não se coloca a serviço da exaltação nacionalista, já que sua construção lembra "a técnica dos cenáculos franceses do seu tempo, e a obra de Kipling que havia lido muitos anos atrás". ${ }^{23}$ Se para Borges os textos de Sarmiento interessam como antecedentes a fim de construir uma tradição argentina que defende valores universais decisivos, da mesma forma que é o primeiro que se desfaz de "limitações locais", essa visão voltará de outra forma em Don Segundo Sombra, um texto no qual o moderno anda lado a lado com o popular tradicional, como nos dois contos orais que narra Don Segundo ao assombrado discípulo Fabio Cáceres.

Do outro lado do Rio da Prata, outro Estado nacional divide uma geografia física e humana que faz com que Borges veja a identidade comum. A própria insistência em chamar de Banda Oriental a este território que perdeu essa denominação durante a terceira década do século XIX, revela uma preferência por um sintagma de ressonâncias épicas e, talvez, mais definido e belo que o excessivamente topográfico e confuso República Oriental do Uruguai ou o mais sintético de Uruguai. Como a antiquada María Justina Rubio de Jáuregui, de seu conto "La señora mayor", Borges também "impunha" arcaísmos: "[Decía] orientales

22. Citado em ANTELO. Na ilha de Marapatá, p.184-185. Em um breve artigo, concluiu: "O narrador de Don Segundo não é o jovem agauchado; é o nostálgico homem de letras que recupera, ou sonha recuperar, numa linguagem na qual convivem o francês e o chimarrão, os dias e as noites fundamentais que aquele não fez nada mais que viver" ("Sobre Don Segundo Sombra", em Sur, Buenos Aires, n. 217-218, novembro-dezembro 1952). E em uma pós-data de 1974 ao seu prólogo de Versos, de Evaristo Carriego, anotou: "A poesia trabalha com o passado. [...] O verso exige a nostalgia, a pátina, nem ao menos superficial, do tempo. Também podemos perceber isto no curso da literatura gauchesca. Ricardo Güiraldes cantou o que foi, o que pode haver sido, seu Don Segundo, não o que era quando ele redigiu sua elegia" (BORGES. Prólogos con un prólogo de prólogos, p. 42). Sobre as relações entre Borges e Mário de Andrade e, em particular, o caso Güiraldes, cf. Antelo, Na ilha de Marapatá (Mário de Andrade lé os hispanoamericanos).

23. BORGES. Prosa completa, II, p. 220. 
y no uruguayos". ${ }^{24}$ Essa noção de "outra Banda" permite aproximadamente, desde meados do século, estabelecer um sutil paralelo de distanciamento e de assimilação cultural, já que definido nesses termos um rio, apenas, e somente alguns "acidentes" políticos separam o que está próximo: a mesma língua, os mesmos tipos humanos autóctones, os mitos comuns (ou quase) construídos em poucos séculos, a mesma "pánica llanura interminable" ("pânica planície interminável"), como a chama Emilio Oribe num poema que Borges citou com satisfação em diversas ocasiões. E "cerca del Brasil" ("perto do Brasil"), ou seja, perto, mas diferente, como se a planície terminasse nos limites políticos com o país de língua portuguesa. ${ }^{25}$ Observando bem, isto explica a semelhança e a diferença das imagens de Borges sobre o lado oriental do Prata, sua profunda simpatia, a forma como fica tão à vontade quando menciona estas terras, sua gente, sua cultura. Tudo isso tem, para ele, o sabor do que é próprio e do que não é tão desconhecido: "Es el sabor de lo que es/ Igual y un poco distinto" ("É o sabor do que é/ Igual e um pouco diferente"); dois territórios que, em um arranque de indefinido anarquismo, são avaliados como separados artificialmente, se bem que o autor confia em "que el tiempo/ Vaya borrando

\section{BORGES. Prosa completa, II, p. 403.}

25. "Era allá en Melo/ ciudad de coloniales casas/ en medio de la pánica llanura interminable/ y cerca del Brasil" ("Era lá em Melo,/ cidade de casas coloniais/ em meio da pânica planície interminável,/ e perto do Brasil", é o primeiro quarteto do poema "El grito", do livro El Halconero Astral (1919), de Emilio Oribe (1893-1975), a quem Borges conheceu pessoalmente. O terceiro verso foi intercalado no texto de "Avelino Arredondo" (El libro de arena, 1975) sem menção da fonte. Sobre esses versos de Emilio Oribe posso dar fé da obsessão borgiana baseada em dois testemunhos. O poeta uruguaio Fernando Pereda (1899-1994) me relatou, no ano de 1990, que se encontrou com Borges em Buenos Aires por volta de 1960, que lhe perguntou, de entrada: "Diga-me, em Montevidéu continuam acreditando que Oribe é um bom poeta?" Ao que Pereda respondeu: "E quem foi que lhe disse que Oribe é um poeta?", com isso ironicamente o uruguaio jogava com desdém com o autor de "El grito" e com o ódio de Borges pelo fundador do Partido Branco, o general Manuel Oribe, aliado de Rosas durante a Guerra Grande (1839-1851). Segundo Pereda, seu interlocutor ficou sem resposta. Em outra ocasião, em Buenos Aires, em 1995, o poeta argentino Jorge Calvetti, amigo de Borges desde a juventude, desde o final da década de 1930 e também bom conhecedor da pessoa e da obra de Emilio Oribe, me comunicou que Borges citava com veneração os versos mencionados, mas que apenas usava: "Coloniales casas", que estranho, não é mesmo? Por que não "casas coloniales"?" 
fronteras;/ Por algo tienen los mismos/ Colores las dos banderas" ("que o tempo/ Irá apagando fronteiras; Por algum motivo tem as mesmas/ Cores as duas bandeiras") ["Milonga para los orientales"]. ${ }^{26}$ Nem é preciso ir tão longe, por exemplo, é fácil observar que a unidade desta paisagem explica as apropriações resultantes e, em contraposição, advertir a inexistência do norte argentino ou da região andina no discurso borgeano.

Não é de se admirar, então, que o gaúcho e o caudilho uruguaio apareçam na obra de Borges tanto ou mais que os argentinos, tanto os que ele imaginou ou reinventou em seus próprios textos quanto os que lhes foram proporcionados pela história, entre estes últimos em particular o chefe rural Aparicio Saravia, homem da fronteira uruguaio-brasileira, líder do Partido Blanco ou Nacional desde 1897, mas que antes lutou no Brasil na Revolução federalista de 1893-1895, sob as ordens do seu irmão Gumersindo Saraiva. Durante sua juventude, Borges renegou a noção de fronteira política entre os dois Estados do Prata, como é possível perceber em seus artigos redigidos entre 1924 e 1929. Por exemplo, num pequeno artigo sobre o uruguaio Vicente Rossi (1871-1945), desde jovem radicado na Argentina, onde realizou uma extensa obra de cronista, narrador e de intérprete da voz de Martín Fierro, Borges nega a tese de Rossi sobre a existência de um vivo "idioma gauchesco" oposto ao castelhano, "uma linguagem não dita e secreta - ironiza - que apenas a omissa distração dos espanhóis (...) pode compreender". Essa invenção própria não é incumbência, nesses termos, - diz Borges - "aos argentinos de ambas as margens". 27 Visto dessa forma, mais ou menos em 1933, quando publica essa nota, não existiriam dois países diferenciados, mas sim um rio que dividia o comum meio da Pampa: a ocidental, que está na Argentina, mas que não ocupa todo seu território, mas apenas a porção mais significativa e mais crioula; a oriental, que está no Uruguai e no Rio Grande do Sul. Mas este último território, uma vez incorporado ao Estado brasileiro, e em consequência à língua portuguesa, se desmembrou da maior unidade linguística pratense.

As semelhanças entre as duas Bandas se elevam à máxima potência na admiração de Borges pelo romance de um narrador fronteiriço: William Henry Hudson, quem, em seu The purple land that England lost (1885), conseguiu a

26. BORGES. Obra poética, 1923-1976, p. 297-299.

27. BORGES. Borges en Revista Multicolor. Obras, reseñas y traducciones inéditas de Jorge Luis Borges. Diario Crítica: Revista Multicolor de los Sábados, 1933-1934, p. 219. 
façanha "dos muito poucos livros felizes que há na terra", conforme afirmou em um artigo maduro que publicou em Otras inquisiciones. ${ }^{28} \mathrm{Um}$ livro escrito em inglês por um argentino, de pais norte-americanos, e que depois de passar vinte e poucos anos em sua terra natal se radicou na Inglaterra até sua morte. Nada melhor para quebrar o fetiche da literatura nacional que corre ao longo de todo o século XIX e, pelo menos na Argentina, continua gravitando durante a primeira metade do século XX, ninguém melhor que este Hudson fronteiriço da língua, da pátria e da literatura, um argentino transferido à Inglaterra, o império tão odiado pelo nacionalismo rio-pratense, particularmente vigoroso em meados do século; aquele país de idioma tão amado por Borges, o que usou desde a infância em seu lar, ao qual traduziu dezenas de textos literários que admirou e até ensinou como professor quando já era um homem maduro (Arias/Hadis, 2000). ${ }^{29}$ É muito interessante marcar que Borges não recupera Allá lejos y hace tiempo, o romance de Hudson sobre a Argentina, mas La tierra purpúrea, o livro sobre a Banda Oriental, como a chama Hudson, que também se recusa a chamar de Uruguai ao Uruguai. A fundamentação dessa opção, no artigo de 1952, supera toda estimativa literária de superioridade de um relato sobre outro e inclusive qualquer outra consideração estrita ou puramente literária:

(...) o âmbito que abrange The purple land é incomparavelmente maior. O Martín Fierro (apesar do projeto de canonização de Lugones) mais que a epopéia das nossas origens - em 1872! - é a autobiografia de um bandoleiro (...) Don Segundo Sombra, apesar da veracidade dos diálogos, está pervertido pelo afã de engrandecer as tarefas mais inocentes. (...) Güiraldes dá um tom mais grave à voz para mencionar os trabalhos cotidianos do campo, Hudson (como Ascasubi, como Hernández, como Eduardo Gutiérrez) narra com toda a naturalidade fatos provavelmente atrozes. (...) Outro acerto de Hudson é o geográfico. Nascido na província de Buenos Aires, no círculo mágico da pampa, escolhe, entretanto, a terra púrpura onde o pelotão de cavalaria exauriu suas primeiras e últimas lanças: o Estado Oriental. ${ }^{30}$

28. BORGES. Prosa completa, II, p. 257.

29. ARIAS; HADIS. Borges profesor. Curso de literatura inglesa na Universidad de Buenos Aires.

30. BORGES. Prosa completa, II, p. 256-257. 
Nesse ensaio Borges peca pela autocitação, porque "La tierra cárdena", como chama a Banda Oriental em uma livre tradução de The purple land, é o título de um artigo juvenil incluído em El tamaño de mi esperanza (1926), no qual já confessava sua inveja por tanta felicidade, já traçava um paralelo entre este relato e o Martín Fierro, mas onde anotava que Richard Lamb - protagonista do romance - "percorre palmo a palmo o campo uruguaio". 31 O campo uruguaio, não o da Banda Oriental, como Hudson prefere. Se a admiração pelos dotes do primeiro romance de Hudson foi prematura, a certeza de que as duas Bandas eram, substancialmente, uma só, ou que uma parte de uma das Bandas era quase igual à outra, podia encontrar alguma hesitação no precoce ensaísta. Tanto que, no encerramento da citação transcrita, pela primeira vez, reconhece sem duvidar a condição de "Estado" ao Uruguai, mesmo que, através de uma nova pirueta, mostre preferência pelo primeiro gentílico ("oriental"). Uma vez que se confirmou a certeza do apagamento das fronteiras não houve mais mudanças na forma de ver.

Quando em suas ficções, em seus ensaios ou ainda em suas declarações públicas identifica algum espaço será o da "pampa" crioula, mas sempre a pampa de origem bispânica. Por isso não entra nesse registro o Rio Grande do Sul, ou entra na forma subsidiária, limítrofe, como o único território com o qual esse pampa outro tem fronteira: com o Uruguai. Pouco diz Borges sobre o Brasil, como cenário e como literatura, além do Rio Grande do Sul. Há alguma prova de admiração sobre Os Sertões, de Euclides da Cunha, no qual com certeza Borges encontrou os visíveis ecos de Facundo. Em uma ocasião, por exemplo, utiliza o grande livro de Euclides para explicar a paixão romântica da poesia e da vida do argentino Almafuerte, sem descuidar do matiz irônico: "A princípios da era cristã, na Ásia Menor ou na Alexandria, [Almafuerte] teria sido considerado um herege, um sonhador de arcanas redenções e um tecelão de fórmulas mágicas; em plena barbárie, um profeta de pastores e de guerreiros, um Antônio Conselheiro.”32

Seja como for, as poucas vezes nas quais Borges pensou no Brasil, o viu como o território da barbárie, daquilo que é remoto. Uma vasta terra atrasada e mestiça onde - como acreditava Sarmiento, em quem provavelmente deve ter se inspirado - "mais que em nenhum outro lugar, se desenham as diferenças entre a

31. BORGES. El tamaño de mi esperanza, p. 34.

32. BORGES. Prólogos con un prólogo de prólogos, p. 15. 
vida européia e a vida indígena”. ${ }^{33}$ Ou seja, um país quase infinito onde a civilização e a barbárie dificilmente podem se conciliar. Todas as vezes que mencionou o Brasil em seus contos o fez em suas histórias de contrabandistas, que passam de um lado ao outro desde a obscura fronteira uruguaia e do Rio Grande do Sul. Esse cenário de violência e delito pode ser visto, por exemplo, em dois contos reunidos no volume El Aleph (1949): "El muerto" e "Emma Zunz". No primeiro, há um sinistro personagem, o brasileiro Azevedo Bandeira, que deixa seu subordinado prosperar, o portenho Benjamín Otárola, um compadrito presunçoso, para depois possuir a sua mulher. Mas o faz de forma a planejar um crime abominável com o qual nem ao menos manchará as mãos, pois será executado por um capanga. $O$ primeiro retrato de Bandeira diz muito sobre a visão que Borges tem do Brasil: "Alguém opina que Bandeira nasceu do outro lado do Cuareim, no Rio Grande do Sul; isso, que deveria rebaixá-lo, obscuramente o enriquece de selvas populosas, de pântanos, de inextricáveis e quase infinitas distâncias." ${ }^{34}$ Por outro lado, já quase chegando ao século XX, em "Emma Zunz", um provável vigarista argentino-judeu de origem alemã se refugia em um hotel de Bagé, como se a pequena cidade rio-grandense fosse um lugar do far west, aonde não chega o braço da lei ou da justiça.

Há um fragmento da sua vida muito conhecido, um episódio que repetiria em diversas ocasiões, que referenda essas observações presentes na ficção. ${ }^{35}$ Em uma entrevista oferecida em Montevidéu em 1963, na qual a resposta dada é uma associação espontânea a uma palavra proposta, ao ouvir a palavra "Latinoamérica", resgata uma obsessão:

Não conheço quase nada de América Latina. Argentina, Uruguai, e passei alguns dias em Santa Ana do Livramento, na fronteira com o Brasil, onde tive a casualidade de presenciar um assassinato. Estávamos em uma confeitaria, com Amorim, e havia na outra mesa um guarda-costas de alguém importante, um capanga. Um bêbado se aproximou do capanga e ele o matou com dois balaços. No dia seguinte, o capanga em questão estava na mesma confeitaria tomando um refresco. Foi na mesa do lado, mas conto o que me contaram depois, e esta lembrança é mais clara que a realidade. Eu somente vi um homem que chegava e parava e escutei o estrondo. ${ }^{36}$

33. Trata-se de um texto de Domingo F. Sarmiento, datado em 1844. Citado em Ana María Barrenechea, 1978, p. 28-29.

34. BORGES. Prosa completa, p. 26.

35. RODRíGUEZ MONEGAL. Borges, una biografía literaria, p. 233-235.

36. PERALTA. Media hora con Borges: La electricidad de las palabras. 
América Latina somente significa para Borges, e isso já em1963, um espaço vazio, a aceitação plena do seu desconhecimento e, por último, a única e perplexa argumentação de um crime que aconteceu no Rio Grande do Sul, território tão desconhecido para um portenho, terra que enlaça sem hesitar a brutalidade e o crime. Esse mesmo episódio havia sido retocado ou recriado na "Posdata de 1947" do relato "Tlön, Uqbar, Orbis Tertius" (de Ficções, 1944, I: 422):

Uma casualidade que me inquieta fez que eu também fosse testemunha da segunda (intromissão do mundo fantástico no mundo real]. Esse fato ocorreu alguns meses depois, na mercearia de um brasileiro, na Cuchilla Negra. Amorim e eu voltávamos de Sant'Anna. Uma cheia do rio Tacuarembó nos obrigou a experimentar (e a suportar) essa rudimentar hospitalidade. O dono da mercearia nos acomodou em uns leitos que rangiam em um cômodo grande, entupido de barris e couros. Deitamos, mas não nos deixou dormir até o amanhecer a bebedeira de um vizinho invisível, que alternava insultos incompreensíveis com fragmentos de milongas, ou melhor, com fragmentos de uma única milonga. Como é de se supor, atribuímos essa gritaria insistente ao fogoso vinho do dono... De madrugada, o homem estava morto no corredor. A aspereza da vOZ nos havia enganado: era um rapaz jovem. (...) Um paisano propôs que o jogassem na correnteza do rio. Amorim comprou o corpo mediante alguns pesos. Ninguém sabia nada do morto, exceto "que vinha da fronteira". ${ }^{37}$

O impressionante episódio da bárbara violência nas proximidades do Brasil se projetou (e distorceu) sobre sua leitura de La carreta (1932), do seu amigo e primo político Enrique Amorim. Porque ao compará-lo com Don Segundo Sombra, indica que neste último romance priva a "lembrança reverente e nostálgica", ao passo que no de Amorim está "a atual campanha oriental: a dura campanha do Norte, terra de gaúchos taciturnos, de touros vermelhos, de perigosos contrabandistas (...) de 'estâncias' que estão abandonadas como um barco no mar". ${ }^{38}$ Em um conto como "El otro duelo", de El Informe de Brodie (1970), no qual se enfrentam "dois gaúchos de Cerro Largo, Manuel Cardoso e Carmen Silveira", volta a aproximar a imagem da fronteira entre Uruguai e Brasil com a morte violenta. O mesmo que

37. BORGES. Ficções, I, p. 422.

38. BORGES. Prólogo de Jorge Luis Borges a la edición alemana de La Carreta, p. 61. 
em "La otra muerte", de El Aleph, no qual o enterriano Pedro Damián permite este mundo, em uma das duas versões possíveis, como um valente que luta nas hostes de Saravia na revolução de 1904. Ou em "Avelino Arredondo", do El Libro de Arena (1975), em que o protagonista mata ao presidente Idiarte Borda, da mesma forma que narra a história e as crônicas da época, em plena guerra civil de 1897, quando ocorre o levante do "gauchaje de Aparicio Saravia". ${ }^{39}$ Ou, algo mais sutil, em "La espera" (El Aleph), em que o falso Alejandro Villari "vai de carro de encontro à morte": chega a Buenos Aires tendo passado a noite em um "hotel de Melo", anacronismo patente e irônico com o mal-informado leitor em geografia uruguaia. Melo, a sessenta quilômetros da fronteira com o Brasil, era "o centro de operações de Aparicio Saravia”, como foi chamado por Roberto J. Payró em suas notáveis crônicas do diário portenho La Nación sobre a frustrada revolução de $1903{ }^{40}$ Borges nunca esteve ali, mas sabia muito bem que essa pequena cidade, nascida em 1795 para servir de posto militar a fim de deter o avanço português, era o último e mais complexo limite político da pampa hispano-gaúcha e o último reduto épico (ou seja: literaturizável) da barbárie caudilhesca e do gauchismo. O mesmo ímpeto "bárbaro" que, ao final do século XIX, havia sido perdido na pampa ocidental.

Há um pouco de ingenuidade na forte concatenação causal entre a lembrança de um crime e Rio Grande do Sul, mas parece muito mais que se tratara da afirmação de um férreo juízo de valor - não de um preconceito -, de caráter sarmientino. Trata-se de uma fundada opinião deste liberal conservador quanto à forma decimonônica, que lhe fez temer ou suspeitar de todo lugar, de toda cultura que não atingida pelo amado braço da "civilização". Além da atração que sentiu pela épica fundacional, a coragem, o hábil manejo da faca e esse saber se arriscar completamente dos crioulos ou dos orilleros reais. Não pelos personagens que ele imaginou, e que continuam povoando nosso mundo de leituras e de imagens.

39. ROCCA. Borges y el Uruguay, p. 2.

40. PAYRÓ. Crónicas de la revolución de 1903. 


\section{A literature of the borders: Jorge Luis Borges, fictions and debates}

Abstract: Borges' literature has until recently been regarded as one of the most exquisite expression of universal resources in Spanish language, with very little relationship with the Latin American context or the most important problems of that continent. Meanwhile, this literature has shown a strong tension with other texts that debate the political problems of these latitudes. This article studies these relationships and, in particular, deepens in the borderline position of Borges' work in relation with the symbolic and political levels that come face to face with the States of the Rio de la Plata or Brasil. Keywords: Jorge Luis Borges, border, Argentina, Brazil, Uruguay.

$$
\text { Referências }
$$

ANTELO, Raúl. Na ilha de Marapatá (Mário de Andrade lé os hispanoamericanos). São Paulo: HUCITEC/INL, 1985. (Recolhe as notas de Mário de Andrade sobre "Literatura modernista argentina"].

ARIAS, Martin; HADIS, Martín (Edición, investigación y notas). Borges profesor. Curso de literatura inglesa na Universidad de Buenos Aires. Buenos Aires: Emecé, 2000.

BARRENECHEA, Ana María. Las ideas de Sarmiento antes de la publicación del Facundo. In: Monte Ávila, 1978. Textos Hispanoamericanos. De Sarmiento a Sarduy. Caracas:

BORGES, Jorge Guillermo. El caudillo. Buenos Aires: Academia Argentina de Letras, 1989. Prólogo de Alicia Jurado. [1921].

BORGES, Jorge Luis. Inquisiciones. Barcelona: Seix Barral, 1994. [1925].

BORGES, Jorge Luis. El tamaño de mi esperanza. Barcelona: Seix Barral, 1993. [1926].

BORGES, Jorge Luis. El idioma de los argentinos. Barcelona: Seix Barral, 1994. [1928].

BORGES, Jorge Luis. Prólogo de Jorge Luis Borges a la edición alemana de La Carreta. In: Borges en El Hogar, 1935-1958. Buenos Aires: Emecé, 2000. [1937].

BORGES, Jorge Luis. Aspectos de la poesía gauchesca. Montevideo: Número, 1950.

BORGES, Jorge Luis (en colaboración con Margarita Guerrero). El Martín Fierro. Buenos Aires: Emecé, 1979. [1953].

BORGES, Jorge Luis. Prólogos con un prólogo de prólogos. Buenos Aires: Torres Agüero, 1975.

BORGES, Jorge Luis. Obra poética, 1923-1976. Buenos Aires: Emecé, 1977.

BORGES, Jorge Luis. Prosa completa. Barcelona: Bruguera, 1980. 2 v.

BORGES, Jorge Luis. Ficcionario. Una antología de sus textos. México: Fondo de Cultura Económica, 1985. (Edición, introducción, prólogos y notas por Emir Rodríguez Monegal). [Incluye el artículo "Déle, déle"]. [1981]. 
BORGES, Jorge Luis. Borges en Revista Multicolor. Obras, reseñas y traducciones inéditas de Jorge Luis Borges. Diario Crítica: Revista Multicolor de los Sábados, 19331934. Buenos Aires: Atlántida, 1995. (Investigación y Recopilación de Irma Zangara).

FLÓ, Juan. Vindicación o vindicta de Borges. In: . Borges el último laberinto. Montevideo: Linardi y Risso, 1987: 153-242. [Segunda versión del prólogo a la recopilación Contra Borges. Buenos Aires: Galerna, 1978].

GÜIRALDES, Ricardo. Don Segundo Sombra. Madrid: ALCCA XX/Fondo de Cultura Económica, Colección Archivos/UNESCO, 1996. Edición de Paul Verdevoye. [1926].

HERnÁNDEZ, José. Martín Fierro. Poesía gauchesca. Caracas: Biblioteca Ayacucho, 1977. (Prólogo de Ángel Rama. Edición, cronología y notas de Jorge B. Rivera). [1872, 1879].

HERNÁNDEZ, José. Martín Fierro. Madrid: Colección Archivos/UNESCO, 2001. Edición de Élida Lois y Ángel Núñez. [1872, 1879].

JITRIK, Noé. José Hernández. Buenos Aires: CEDAL, 1971.

LAFFORGUE, Martín (Comp.). AntiBorges. Buenos Aires: Javier Vergara, 1999.

LUDMER, Josefina. El género gauchesco. Un tratado sobre la patria. Buenos Aires: Sudamericana, 1988.

PAYRÓ, Roberto J. Crónicas de la revolución de 1903. Montevideo: Banda Oriental, 1968.

PERALTA, Carlos. Media hora con Borges: La electricidad de las palabras. Marcha, Montevideo, n. 1171, 30 ago. 1963, p. 9. [Entrevista]

RAMA, Ángel. Prólogo a Poesía gauchesca. Caracas: Biblioteca Ayacucho, 1977. (Antología, notas y cronología de Jorge B. Rivera).

RAMA, Ángel. La ciudad letrada. Montevideo: Arca/FAR, 1984.

ROCCA, Pablo (Ed.). Borges y el Uruguay. Montevideo: Facultad de Humanidades y Ciencias de la Educación/Universidad de la República/ Linardi y Risso, 2001.

ROCCA, Pablo. Uno o dos destinos sudamericanos (Ficción y realidad en Avelino Arredondo). Revista Iberoamericana, Pittsburgh, n. 194-195, p. 161-172, enerojunio 2001.

ROCCA, Pablo. Ángel Rama, Emir Rodríguez Monegal y el Brasil: Dos caras de un proyecto latinoamericano. Montevideo: Ediciones de la Banda Oriental, 2006.

RODRÍGUEZ MONEGAL, Emir. Borges, una biografía literaria. México: Fondo de Cultura Económica, 1987. (Traducción de Homero Alsina Thevenet). [1981].

SARLO, Beatriz. Borges, un escritor en las orillas. Buenos Aires: Ariel, 1995.

SARMIENTO, Domingo F. Facundo. Civilización o barbarie. Caracas: Biblioteca Ayacucho, 1976. (Prólogo de Noé Jitrik. Cronología de Nora Dottori y Susana Zanetti). 